As far as the brain is concerned, no objective changes are indicated. The "nervousness" which is definitely present, may be amply justified on psychical grounds (childless condition) and for other reasons as well.

After six months' observation no changes in the condition of the eye could be noted.

\title{
REFERENCES
}

1. LEBER.-Krankheiten der Netzhaut in Graefe-Saemisch-Hess Handbuch der gesamt. Augenheilk., Bd. VII, 1916.

2. Karasek.-Angiomatosis Retinae. Klin. Monatsbl. f. Augenheilk., Bd. XCV.

3. Prevec.-Ein Fall von angiomatosis retinae. Klin. Monatsbl. $f$. Augenheilk., Bd. XCVI.

4. Ludwig. Ueber Angiom der Aderhaut mit Feuermal der Schlaefengegend. Klin. Monatsbl.f. Augenheilk., Bd. XCV.

5. NicCOL and MOORE - A case of angiomatosis retinae. Brit. Jl. of Ophthal., Vol. XVIII.

6. Junius. - Zur Frage der Angiomatosis Retinae. Ergebnisse und Folgerungen. Klin. Monatsbl. f. Augenherlk., Vol. XCI.

7. Rochat.-Familiaere Angiomatosis Retinae und Kleinhirn-angiom. Klin. Monatsbl. f. Augenheilk., Bd. LXXVIII.

8. CRUKRASz.-Angiogliosis retinae with report of two cases. Brit. Jl. of Ophthal., Vol. XXI.

\section{THE MICROSTRUCTURE OF EPITHELIAL CELLS AND ITS IMPORTANCE FOR THE AETIOLOGY OF TRACHOMA*}

\author{
BY \\ Professor Dr. Wilhelm Grüter \\ MARBURG
}

AN analysis of the different cell bodies, in particular of Prowaczek's bodies, presupposes thorough knowledge of all microstructures of the normal cell. Reliable judgment can be formed only from comparative study of the effect of organic and inorganic (chemical) reagents.

Analysis of the apparatus of Golgi occupies the front rank. There is considerable difference of opinion as to its existence in vivo. Some research workers consider it to be artificially produced, while others, e.g., Zeiger, claim that it is invisible in the dark field in vital examination.

\section{Material and Technique of Investigation}

Material.-Variola vaccine, herpes, diphtheria toxin, staphylococcic toxin, mustard oil, trachoma and conjunctivitis blennorrhoeica.

\footnotetext{
* Report read at the International Congress of Ouhthalmology, December 10 1937. Translation by the International Organisation against Trachoma.
} 
Methods.-Staining with haematoxylin-eosin, iron-haematoxylin, giemsa, Lindner's contrast-stains, Biondi-Heidenhain and several special stains, also osmium impregnation by KolatschewNassonow's method, Janus green.

Vital Examination against the light with oblique condenser, dark field (with ultra-violet light), hydrous neutral red and methylene blue solutions.

The examination of material dealt partially with experimentally produced inflammatory processes on the cornea of rabbits and partially with human material. The various individual results were verified by comparative studies of inflammation set up by these toxins.

Photographic filming of cell conditions by Leica film and suitable enlargement.

I succeeded in proving that Golgi's apparatus is not an artificial product of staining but a substantial nuclear structure of characteristic shape and fissiparism. This coroniform structure surrounds the nucleus and can be seen particularly well in flat cells (flat section or vital suspension). It is a three-dimensional reticulated structure with honeycomb-shaped interstices. In the nodes are fine granules which must be considered as products of secretion, to judge by the vital stain with neutral red and according to present anatomical terminology. These granules have the shape of very minute micrococci and show the same type of fissation, new granules separating from the primary structure after fission. Within this coroniform Golgi zone are found ballonets, perfectly transparent, which become more distinct with the progress of inflammation and also divide by fission into minute transparent bubbles. Frequently large blisters are formed by the cohesion of primary and secondary ballonets. These "foamlike" structures are met with not only in the coroniform Golgi zone, but also scattered through the cytoplasmic zone.

While Golgi's apparatus has so far been considered a coroniform structure surrounding the nucleus, my investigations show that Golgi's apparatus is a regular reticulated capsule enclosing not only the nucleus but also another polyhedral structure which latter forms a normal part of the cell and undoubtedly belongs to the nuclear zone, both topographically and structurally. It is a regular polyhedron built up of numerous other small polyhedra. This structure, round or slightly flattened and ovoid, occurred in the epithelium examined, under the nuclear cavity and was connected with the nucleus by a reticulation (a portion of the Golgi apparatus). The latter and the polyhedral structure referred to are in their turn surrounded by the Golgi capsule already described which shows a callosity (coroniform portion of Golgi's apparatus) at the spot where the nucleus and the polyhedral body 
are in contact. This polyhedral body, called " interior reticulated body," can be observed in its peculiar form and topographical relation only in an inflamed cell, but this pathological condition allows of judging the normal conditions in vivo (seen against the light) and thus will not be visible in the dark field and it stains to any appreciable extent only when inflammatory swelling and clouding has caused its physical and chemical property to change. This " interior reticulated body" can thus be shown particularly clearly in keratitis due to variola vaccine or to herpes, either in the dark field or by means of various staining methods (osmium impregnation or vital staining of fresh preparation with neutral red). (n such occasions it will be seen that this interior reticulated body is unusually liable to swell, something like a sponge and reacting easily-to very different physiological and pathological stimuli (dark field photographs of physiologically irritated and herpetically inflamed cell). Observation in the dark field also shows that this polyhedral structure multiplies by fissure, forming new polyhedral buds anywhere on the surface. In every inflamed cell (in acute inflammation more quickly and strongly than in chronic inflammation) a diffuse fine sediment develops, of silverygrey reflection in the dark field and assuming a yellowish-red to orange red tinge by almost any eosin stain. These observations would seem to indicate that the inflammatory sediment in the polyhedral structures is albumen. Osmium impregnation colours this inflammatory sediment an intense black. Staining with Soudan gave negative results, showing that fatty degeneration was not responsible. The same colouration or clouding of albuminous sediment is observed also in the reticular nodules, i.e., the secretory granules in the inflamed cell, so that the contents stain reddish with eosin, while the cocciform capsule retains a more or less bluish red (haematoxylin) shade.

This " interior reticulated body" has been repeatedly referred to before in literature, e.g., by Hückel (1898) in describing keratitis of rabbits set up by variola vaccine; nothing further has, however, become known as to its peculiar fission and its occurrence in the normal cell. The various virus diseases of this structure have already been described in modern literature (eosinophil polyhedron) without any definite data as to its origin and relations to the various cell structures.

\section{Observations in Trachoma}

On examination of epithelium in trachoma and conjunctivitis blennorrhoeica the following observations were made as a result of vital and staining methods :-

1. The secretory granulations swell and divide in the trachomatous epithelium. This process is diffuse (both in Golgi's 
apparatus and in the cytoplasmic zone) or focal (hood-shaped) (osmium impregnation).

2. The ballonet structures referred to above swell up and divide both in the zone of Golgi and in the cytoplasmic zone.

3.-The " interior reticulated body" swells and turns cloudy (as can be seen clearly in the dark field and against the light). Typical signs of division then appear (fission of the polyhedral parts). An albuminous sediment forms in the honeycomb-like spaces in the polyhedral parts (visible in dark field and by eosin staining). Lastly, appear fine nodules and still finer granules (like strings of pearls) on the interior reticulated body.

The Hood-shaped structure (Prowaczek's bodies) are not homogeneous but consist of various partial structures :-

(a) Focal proliferation of Golgi's sheath with more pronounced proliferation of the secretory granules (osmium images). These have also been described by V. Reiss (Arch. f. Ophthal., 1913).

(b) Interior reticulated body or partial structures protruding from under the nuclear calotte. Extremely fine nodules and granules appear (elementary bodies according to virus nomenclature).

(c) Combination of $(a)$ and $(b)$, the reticulated body detaching itself and the inflamed Golgi sheath becoming stained with it.

\section{Conclusions}

Inflamed trachomatous epithelial cells cannot be shown to contain any granular structures of a nature different from their own, whether in the Golgi zone, the interior reticulated body as described or in the cytoplasmic zone.

A comparison of Herzberg's Victoria Blue stains with the results mentioned above which were obtained with a number of Grüter's organic and inorganic cell toxins, in particular a comparison with epithelium conditions in trachoma, shows that the granular structures produced by many different techniques 'with all cell toxins are absolutely alike. They are seen particularly clearly when photographed in the dark field. It will then be seen again and again that the granules are primarily situated in the nodules, i.e., that as the cell inflammation progresses, the mitochondrial granules become particularly clear. I cannot accordingly claim that the various granular structures described in literature, and tested by me by so many different methods, are foreign substances, i.e., initial structures of a hitherto invisible disease germ in the cell.

I hold the same view in regard to the finding of Busacca, who claims to have shown rickettsias in trachomatous epithelial cells on the strength of examination of cells in yellow fever. I consider that these " trachoma rickettsias " are inflammatory proliferations and divisions of granula which normally occur in the epithelial cells. 